\title{
THE NOVA SCOTIAN INSTITUTE OF SCIENCE STUDENT SCIENCE AWARDS 2006
}

\section{Purpose}

To provide an opportunity for students to have their work recognized by a scientific society and to have it considered for publication in a peer-reviewed scientific journal.

\section{Eligibility}

The competition is open to any student currently enrolled in a degree program at a recognized educational institution.

\section{Categories and prizes}

\section{Undergraduate student}

Three broad categories for competition:

Environmental Sciences

Life Sciences

Physical Sciences e.g. terrestrial ecology, marine biology atmospheric sciences, earth sciences etc. e.g. animal and plant cell biology, medical sciences, biochemistry, physiology etc.

e.g. physics, chemistry, engineering, mathematics, computer science etc.

Three undergraduate prizes are available in each of these three categories:

1st prize

2nd prize

3rd prize
$\$ 200$ plus one year's membership to NSIS $\$ 100$ plus one year's membership to NSIS one year's membership to NSIS

\section{Graduate Student}

Any discipline

Single prize of $\$ 500$ plus one year's membership to NSIS

\section{Scientific Writing}

For an article written by a student in a non-scientific discipline Subject must be relevant to science in Nova Scotia Single prize of $\$ 200$ plus one year's membership to NSIS 